\title{
Assessment of Campylobacter fetus subsp. venerealis molecular diagnosis using clinical samples of bulls
}

\author{
Marta Filipa Silva, Ana Duarte, Gonçalo Pereira, Luísa Mateus, Luís Lopes-da-Costa and Elisabete Silva* (10
}

\begin{abstract}
Background: Campylobacter fetus subsp. venerealis ( $C f v$ ) is the pathogen responsible for Bovine Genital Campylobacteriosis (BGC), a venereal disease of cattle associated with impaired reproductive performance. Although several PCR assays were developed to identify this pathogen, most of them are still poorly evaluated in clinical samples. This study evaluated real-time PCR assays for Cfv detection in preputial samples of bulls $(n=308)$.

Results: The detection at the subspecies level (Cfv) compared four assays: two targeting ISCfe1 and two targeting parA gene. The detection at the species level (C. fetus) considered an assay targeting the nahE gene and a commercial kit for C. fetus identification. At the subspecies level, assays directed either to different targets (parA and ISCfe1), or to the same target (ISCfe1 or parA), showed a high percentage of disagreeing results. All samples positive at the subspecies level $(n=169)$ were negative in $C$. fetus detection assays, which strongly suggests the horizontal gene transfer of ISCfe1 and parA to other bacterial species. This was confirmed by microbiological isolation of three Campylobacter portucalensis strains responsible for false positive results. Sequences with a high level of identity with ISCfel and parA gene of Cfv were identified in C. portucalensis genome.

Conclusions: Overall, this study reveals that PCR assays solely directed to a subspecies target originate a high rate of false positive results, due to the presence of parA and ISCfe1 homologous sequences in other bacterial species, namely of the genus Campylobacter. Although the specificity of these methods may be higher if applied to bulls from herds with clinical features of BGC or in other geographical regions, current PCR diagnosis should couple subspecies and species targets, and further research must be envisaged to identify Cfv specific molecular targets.
\end{abstract}

Keywords: Bovine genital Campylobacteriosis, Campylobacter fetus subsp. venerealis, Molecular diagnostics

\section{Background}

Bovine Genital Campylobacteriosis (BGC) is a venereal disease of cattle, caused by the bacterial pathogen Campylobacter fetus subsp. venerealis $(C f v)$, responsible for reproductive failure and significant economic losses, mainly in beef herds where natural breeding prevails $[1$, 2]. Bulls are asymptomatic carriers, harbouring $C f v$ in the preputial crypts, and infect females during breeding

\footnotetext{
* Correspondence: elisabetesilva@fmv.ulisboa.pt

CIISA - Centro de Investigação Interdisciplinar em Sanidade Animal, Faculdade de Medicina Veterinária, Universidade de Lisboa, Avenida da Universidade Técnica, 1300-477 Lisbon, Portugal
}

[3]. By contrast, $C f v$ infection in females induces endometritis, early embryonic death and abortion [2]. An accurate diagnosis of BGC is essential for implementation of disease control programs and international trade of bulls and semen [4]. However, BGC diagnosis is hindered by the two cattle-associated Campylobacter fetus subspecies, C. fetus subsp. fetus (Cff) and Cfv, with distinct niche preferences but with similar genotypic and phenotypic characteristics [5, 6]. Although Cff inhabits cattle intestinal tract, it can be occasionally recovered from bovine preputial samples and it is responsible for sporadic cases of abortion [1, 7]. The OIE recommended

(C) The Author(s). 2020 Open Access This article is licensed under a Creative Commons Attribution 4.0 International License, which permits use, sharing, adaptation, distribution and reproduction in any medium or format, as long as you give appropriate credit to the original author(s) and the source, provide a link to the Creative Commons licence, and indicate if changes were made. The images or other third party material in this article are included in the article's Creative Commons licence, unless indicated otherwise in a credit line to the material. If material is not included in the article's Creative Commons licence and your intended use is not permitted by statutory regulation or exceeds the permitted use, you will need to obtain permission directly from the copyright holder. To view a copy of this licence, visit http://creativecommons.org/licenses/by/4.0/ The Creative Commons Public Domain Dedication waiver (http://creativecommons.org/publicdomain/zero/1.0/) applies to the data made available in this article, unless otherwise stated in a credit line to the data. 
method for BGC diagnosis is microbiological isolation of C. fetus, followed by the $1 \%$ glycine tolerance test, for which $C f v$ is intolerant and Cff is tolerant [2]. Due to the fastidious growth of $C f v$ and potential overgrowth of other microorganisms, microbiologic techniques are laborious, time-consuming and associated to poor sensitivity [1]. Additionally, $C f v$ can acquire glycine tolerance by mutation or transduction mechanisms being misidentified as Cff [8]. Therefore, molecular biology techniques have evolved as attractive tools for diagnosis of BGC. At the species level, real-time PCR assays to detect the $n a h E$ gene of $C$. fetus were developed and validated, showing high specificity and sensitivity $[9,10]$. However, the identification at the subspecies level is hampered by the high genetic similarity of $C f v$ and $C f f$ [11]. Nevertheless, several PCR assays have been described to identify $C f v$ [12-15]. The most used molecular targets for $C f v$ identification are the parA gene and the ISCfe1 insertion element $[9,10,13,14]$. Assays based on ISCfe1 detection are described as more sensitive than parA-based assays to identify $C f v$ isolates $[9,10]$. Although real-time PCR assays targeting the parA gene were evaluated in clinical samples [13, 16-18], available data is insufficient to allow its routine use for diagnosis of BGC. Assays based on ISCfe1 detection were not yet assessed in clinical samples despite showing promising results on $C f v$ isolates $[9,10]$. Therefore, the diagnostic value of PCR assays for bull clinical samples has not been elucidated. This is a relevant clinical issue because bull testing is the most appropriate prophylactic measure for BGC control. This study evaluated different real-time PCR assays for $C f v$ identification on bull preputial samples in order to assess their suitability for BGC diagnosis.

\section{Results}

\section{Performance of the real-time PCR assays}

The performance of the real-time PCR assays was evaluated using DNA from preputial samples spiked with $C f v$ genome copies. All assays were able to detect 10 to $10^{5}$ Cfv genome copies within 40 cycles of amplification and considering a positivity threshold set to $\mathrm{Ct} \leq 35$, were able to detect $100 C f v$ genome copies. The efficiency (Table 1) was within the acceptable range of $90-110 \%$ [19] and a linear relationship between the cycle threshold $(\mathrm{Ct})$ value and the log of copy number was evidenced by an $r^{2} \geq 0.98$. The intra- and inter-assay coefficients of variation were less than $5 \%$, as shown in Table 1.

\section{Detection of Cfv and C. fetus molecular targets in preputial samples}

Four different assays for $C f v$ identification were tested in clinical samples with unknown BGC sanitary status, targeting the ISCfe1 sequence (ISC-A and ISC-B assays) and the parA gene (parA-A and parA-B assays). The agreement between parA-A and ISC-A assays was evaluated in all the 308 bovine preputial samples. The parA-A assay gave a lower number of positive results $(n=78$, $25.3 \%)$ than the ISC-A assay $(n=155,50.3 \%)(P<0.001)$. This originated a high percentage of disagreeing results $(34.1 \%$, Kappa $=0.32)$, mainly represented by ISCfe1 positive and parA negative samples (Table 2).

The conservation of parA and ISCfe1 sequences was evaluated on a subset of 141 samples, comparing results obtained with assays targeting two different regions of each nucleotide sequence (ISC-A/ISC-B and parA-A/ parA-B assays). The parA-A and parA-B assays provided 28.4 and $7.8 \%$ positive results, respectively, resulting in a high percentage of disagreeing results $(20.6 \%$; Kappa $=$ 0.35 ) (Additional file 1). Likewise, the ISC-A and ISC-B assays originated 58.9 and $17.0 \%$ positive results, respectively, also resulting in a high percentage of disagreeing results $(41.8 \%$; Kappa $=0.25)$ (Additional file 1 ). These differences observed between assays directed towards the same target are statistically significant $(P<$ 0.01 ). The number and percentage of positive samples detected by each assay, or double combination is shown in Fig. 1, for all samples tested by the four assays $(n=$ 141). Results obtained by different assays were highly inconsistent. ParA-B assay provided the lowest number of positive samples $(n=11)$, while ISC-A assay detected the highest number of positive samples $(n=83)$. In contrast, there were no samples tested simultaneously positive by ISC-B and parA detection assays.

The presence of genes from the $C f v$-associated genomic island (GI), which may contain the parA-A gene, was evaluated by PCR. Results showed that genes of this GI (fic1, fic2, virB9, virB11) were detected in 95\% ( $n=$ 18) of the parA-A positive samples (Table 3), and a

Table 1 Performance parameters of the real-time PCR assays

\begin{tabular}{lllllll}
\hline Assay & Slope & Y-Intercept & $r^{2}$ & E (\%) & Intra-assay CV (\%) & Inter-assay CV (\%) \\
\hline ISC-A & -3.3732 & 36.472 & 0.99 & 97.90 & $\leq 1.22$ & $\leq 0.71$ \\
ISC-B & -3.3193 & 37.285 & 0.99 & 100.1 & $\leq 1.41$ & $\leq 0.98$ \\
parA-A & -3.1270 & 38.134 & 0.98 & 108.8 & $\leq 0.81$ & $\leq 1.37$ \\
parA-B & -3.3723 & 40.008 & 0.99 & 97.94 & $\leq 2.01$ & $\leq 1.05$ \\
nahE & -3.4440 & 37.773 & 0.99 & 95.20 & $\leq 1.88$ & $\leq 0.61$
\end{tabular}

E Efficiency of amplification, CV coefficient of variation. 
Table 2 Agreement between parA-A and ISC-A assays

\begin{tabular}{llll}
\hline parA-A & ISC-A & Total \\
\cline { 2 - 3 } & Positive & Negative & \\
\hline Positive & $64(20.8 \%)$ & $14(4.5 \%)$ & $78(25.3 \%)$ \\
Negative & $91(29.5 \%)$ & $139(45.1 \%)$ & $230(74.7 \%)$ \\
Total & $155(50.3 \%)$ & $153(49.7 \%)$ & 308 \\
\hline
\end{tabular}

significant association was found between the presence of the parA gene and $C$. fetus GI genes $(\phi=0.873, P<0.001)$.

To evaluate the specificity of the parA gene and ISCfe1 as $C f v$ diagnostic targets, samples tested positive for at least one of these targets were also tested using a real-time PCR assay to detect the C. fetus specific nahE gene and a commercial diagnostic kit (VetMAX C. fetus kit) approved for C. fetus detection in DNA isolated from clinical samples. These assays detect targets common to both $C$. fetus subspecies (Cff and $C f v)$. All samples $(n=169)$ that tested positive to $C f v$ specific targets (parA gene and/or ISCfe1) were negative in $C$. fetus detection assays.

\section{Impairment of Cfv detection in clinical samples by Campylobacter portucalensis}

To investigate the cause of false positive results, microbiological culture and isolation of Campylobacter spp. was performed in three samples positive to parA and/or ISCfe1 and negative in C. fetus detection assays. Three strains identified biochemically and by $16 \mathrm{~S}$ rRNA gene
Table 3 Comparison of results obtained with the parA-A assay and amplification of $C$. fetus specific $\mathrm{Gl}$ genes

\begin{tabular}{llll}
\hline parA-A & \multicolumn{2}{l}{ Gl-associated genes } & Total \\
\cline { 2 - 3 } & Positive & Negative & \\
\hline Positive & $18(36.7 \%)$ & $1(2.0 \%)$ & $19(38.8 \%)$ \\
Negative & $2(4.1 \%)$ & $28(57.1 \%)$ & $30(61.2 \%)$ \\
Total & $20(40.8 \%)$ & $29(59.1 \%)$ & 49 \\
\hline
\end{tabular}

GI - genomic island; Gl-associated genes - fic1, fic2, virB9, virB11

sequencing as Campylobacter portucalensis [20] were isolated from these samples. These strains were confirmed to be responsible for false positive results in the above $C f v$ detection assays. Whole genome sequencing (WGS) data of the type strain C. portucalensis FMV-PI01 ${ }^{\mathrm{T}}$ (NCBI accession no: VWSJ00000000) allowed the identification of the parA gene $(98.1 \%$ identity with sequence from $C f v$ strain WBT011/99) and of an insertion sequence highly similar to ISCfe1 (93.5\% identity with sequence from $C f v$ strain zaf3). The WGS of FMV-PI01 also showed that parA gene is located in a GI, which is highly homologous to the $C f v$-associated GI with $97.42 \%$ of identity in $80 \%$ of the sequence. The arrangement of parA, fic and T4SS genes in the GI is schematically represented in Fig. 2.

Two of the $C$. portucalensis strains harbouring $C f v$ molecular markers, tested positive for both ISCfe1 and parA gene by ISC-A and parA-A assays, and GIassociated genes, whereas one strain tested positive for ISC-A and negative for parA-A and GI-associated genes.

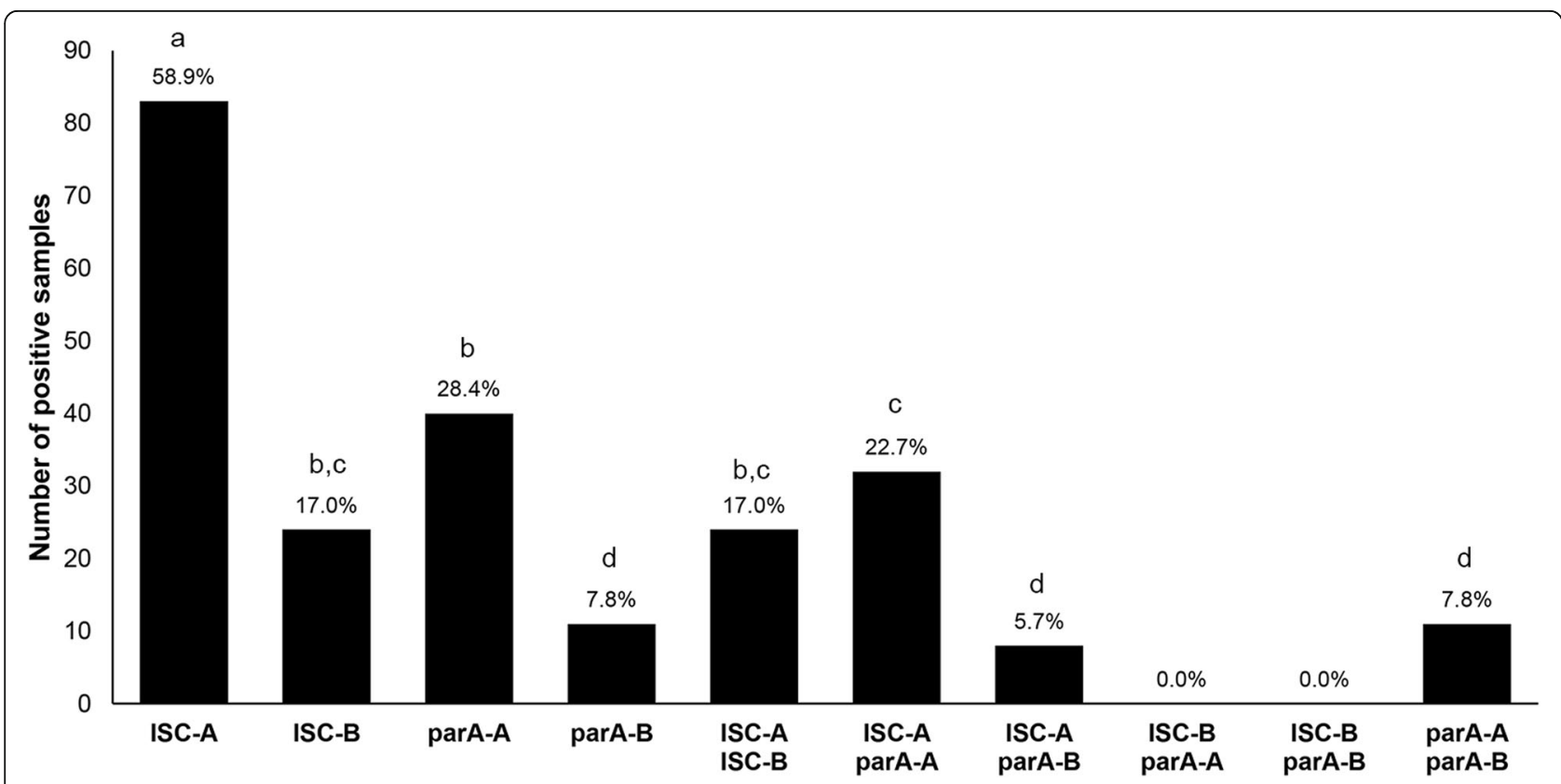

Fig. 1 Distribution of positive results identified by each assay and double combinations of assays $(n=141)$. The percentage of positive results is displayed above the columns. Different letters above columns indicate statistically significant differences $(P<0.05)$ 


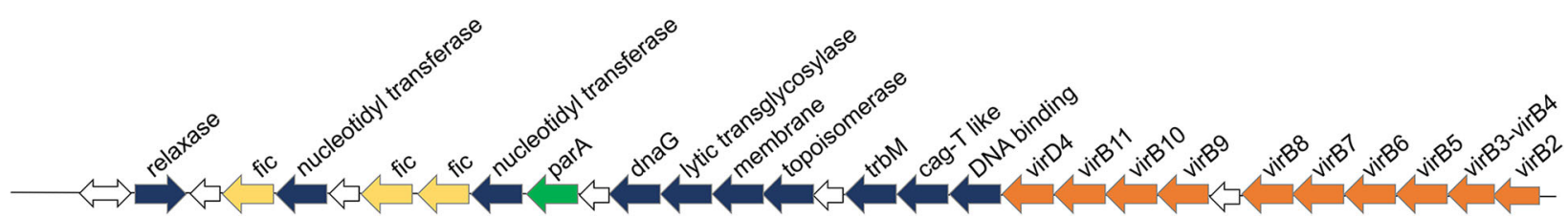

Fig. 2 Schematic representation of the genomic island identified in C. portucalensis FMV-PI01. Orange arrows represent T4SS genes. White arrows indicate genes with unknown function

\section{Discussion}

The analytical performance of the assays used in this study was evaluated using preputial samples spiked with $C f v$ DNA. Assays directed to species and subspecies targets showed similar analytical sensitivities, detecting $10^{1}$ to $10^{2}$ genome copies of Cfv NCTC 10354. All assays provided reproducible results in the same experiment and between experiments, as evidenced by the coefficient of variation $(\mathrm{CV})$ below $5 \%$. Overall, the results showed a good analytical performance of real-time PCR assays and indicate their suitability for detection of $C f v$ in the bovine preputial sample matrix.

A considerable disagreement was observed between results obtained with parA-A and ISC-A assays. This was also observed for assays targeting the same molecular target (ISC-A/ISC-B and parA-A/parA-B), which suggests divergences in the nucleotide sequences of parA and ISCfe1, specifically in primer and probe binding sites. Moreover, in a considerable number of samples only one of the molecular targets was detected. This finding evidences a sensitivity and/or specificity failure of one or both detection assays. Previous studies showed that the parA-based PCR assays have a lower sensitivity when compared with assays targeting ISCfe1 for the identification of $C f v$ isolates $[9,10]$. In fact, parA sequence variation may potentially hinder parA-based diagnostic methods $[16,21]$. On the other hand, at least two different ISCfe1 sequences were found in $C f v$ strains, sharing $98.7 \%$ sequence homology [10]. Therefore, inconsistent results obtained by assays directed towards the same target may result from divergences in the nucleotide sequences.

Samples positive for subspecies specific targets revealed negative in the $C$. fetus detection assays. These samples were expected to be positive for $C$. fetus detection, since the species-specific assays are based on targets common to both $C$. fetus subspecies (Cff and $C f v$ ). The $n a h E$ detection assay showed an analytical sensitivity comparable to that obtained with the subspecies detection assays, indicating that the absence of amplification is not related with differences in the analytical sensitivity. Moreover, although all results obtained with the VetMAX C. fetus kit were negative, the amplification of an internal positive control allowed to validate results. These findings strongly suggest that subspecies targets were horizontally transferred to other bacterial species. Although the parA gene is still used for $C f v$ identification, the horizontal gene transfer of parA to $C$. hyointestinalis isolates and Cff strains was reported [22, 23]. Also, parA detection assays identified putative positive $C f v$ bulls in herds without impairment of the reproductive performance [24] and in virgin bulls [17, 25]. Indeed, the parA gene can be found in mobile genetic elements, namely in a GI almost exclusive of $C f v[26$, 27], in the chromosome and in extra-chromosomal plasmids [21, 27]. On the other hand, genome sequencing data recently deposited in the NCBI database revealed that ISCfe1 can be found in plasmids (e.g. acc. no. CP043436.1), which may facilitate the horizontal transfer of this sequence to non- $C f v$ microorganisms. As a transposable element, ISCfe1 may spread in the genome, thus justifying the variable number of ISCfe1 copies in different $C f v$ strains [14].

Although the possibility of the above targets being transferred horizontally has already been described or suggested, there is no indication in the literature that assays based on these targets can lead to such a high rate of false positive results as those found in this study. In fact, these targets are still used as sole molecular targets for $C f v$ detection, as evidenced in recent studies [28-30]. The rate of false positive results may depend on the geographical region, since previous studies in Canada [18] or Brazil $[28,29]$ reported lower rates of positive results with parA-based assays.

C. portucalensis, which is an inhabitant of the bull's prepuce [20], was identified as a cause of false positive results. The high identity between the sequences found in C. portucalensis and ISCfe1 and parA sequences of $C f v$ suggests the horizontal transfer of these molecular targets. Although C. portucalensis and $C f v$ are not phylogenetically close species [20], the sharing of the same niche by $C f v$ and $C$. portucalensis may have facilitated the horizontal gene transfer of parA and ISCfe1. The genomic island associated to $C f v$, in which the parA gene is included, was found in the genome of C. portucalensis, supporting the results of parA positive samples, with amplification of GI genes (fic1, fic2, virB11, virB9) and without amplification of $C$. fetus specific molecular targets. One of the $C$. portucalensis strains is positive for ISCfe1, without amplification of GI genes or parA. This 
finding suggests an independent horizontal gene transfer of parA and ISCfe1 and may justify the high percentage of samples positive in ISC-A assay and negative in parAA assay $(n=91,29.5 \%)$. The high similarity between the sequences found in $C$. portucalensis and ISCfe1 and parA gene sequences of $C f v$ is enough to impair the accuracy of molecular diagnostic methods based on these targets' detection.

Overall, this study evidenced that ISCfe1 and parA gene-based assays are associated with considerable specificity failures and, consequently, these targets are unsuitable for $C f v$ identification when used solely. However, the detection of ISCfe1 or parA may be used as part of a diagnostic strategy, with validation of positive results to parA or ISCfe1 with previous or subsequent $C$. fetus detection assays. This strategy overcome the specificity failures associated to ISCfe1 and parA detection assays found in this study. Still, as described in previous studies [22, 23, 31], these molecular targets were sporadically found in Cff isolates, leading to false positive results even with the above diagnostic strategy. However, the specificity of these methods is expected to be higher if applied to bulls from farms with reproductive failure, where other causes were ruled out, as described previously [18].

\section{Conclusion}

The results of this study have major implications in the molecular diagnosis of BGC, invalidating the use of ISCfe1 and parA as sole targets for $C f v$ identification. Diagnosis of BGC based solely on these genomic targets originates false positive results, which may lead to the unnecessary treatment or culling of animals. The combined use of $C f v$ and $C$. fetus detection assays should be encouraged as part of the BGC diagnostic strategy, in order to improve the specificity of molecular diagnostic methods. This study also described, for the first time, the presence of the C. fetus GI in another Campylobacter species inhabitant of the bull's preputial mucosa, evidencing that this genomic element can be transferred to other Campylobacter species. A highly homologous sequence of ISCfe1, previously considered a promising $C f v$ molecular marker, and the parA gene, were also found in another Campylobacter species. This evidences the horizontal gene transfer of current diagnostic Cfv molecular targets to other Campylobacter species and prompts for the development of reliable molecular diagnostic tools for BGC diagnosis.

\section{Methods}

\section{Samples and DNA extraction}

This observational study considered samples collected by certified veterinarians, within a bull breeding soundness examination, for diagnostic purposes. The number of tested bulls $(n=308)$ and herds $(n=61)$ is a representative sampling subset of the province of Alentejo, which represents the main beef cattle production area in Portugal, accounting over 10.000 beef cows of several breeds, in natural mating, distributed in the different regions of the province. Herds had unknown sanitary status for BGC, although some showed clinical features compatible with the disease (low breeding season fertility, extended time from bull introduction to conception depicted from calving records, embryo-fetal mortality observed at pregnancy diagnosis). Preputial samples were collected using a scraping/washing technique [32] and were sent to the laboratory under refrigeration conditions. Total DNA extraction was performed using the DNeasy Blood and Tissue Kit (Qiagen), according to the manufacturer's instructions. Extracted DNA was quantified in a Nanodrop 2000C spectrophotometer (Thermo Scientific) and stored at $-20{ }^{\circ} \mathrm{C}$ until use.

\section{Real time PCR assays}

Samples were tested by real-time PCR assays directed to subspecies ( $C f v)$ and species (C. fetus) molecular targets. Detection at the subspecies level $(C f v)$ was performed using four assays, of which two targeting the parA gene (parA-A and parA-B assays) and the other two targeting the insertion element ISCfe1 (ISC-A and ISC-B assays). These pairs of assays, although directed to the same molecular target, detect different nucleotide regions as shown in Table 4. Additionally, two assays were performed for $C$. fetus detection, including an assay targeting the nahE gene and a commercial real-time PCR Kit (VetMAX C. fetus kit, Life Technologies). These two assays are designed to amplify sequences common to both C. fetus subspecies ( $C f v$ and $C f f$ ), and, consequently, do not allow the identification at the subspecies level.

The flow chart of the sampling procedure for $C f v$ and $C$. fetus detection assays is schematically represented in Fig. 3. Briefly, all samples $(n=308)$ were tested with ISC-A and parA-A assays. In addition, a subset of these samples $(n=141)$ was blindly selected to be tested with ISC-B and parA-B assays. Detection of $C$. fetus specific targets was performed in all ISCfe1 and/or parA gene positive samples $(n=169)$.

For all assays, a PCR positive control was used in every experiment, which was prepared by adding 100 copies of Cfv genomic DNA from strain NCTC 10354 to $25 \mathrm{ng}$ of DNA extracted from a $C f v$-negative preputial sample to simulate a $C f v$-positive preputial sample.

\section{Detection of ISCfe 1 insertion sequence: ISC-A and ISC-B assays}

For the detection of the insertion element ISCfe1 two different Taqman MGB probe-based assays were used (ISC-A and ISC-B assays; Table 4). The ISC-A assay was 
Table 4 Real-time PCR assays used for Cfv detection

\begin{tabular}{llll}
\hline Assay & Target & Nucleotide Region ${ }^{\text {a }}$ & Reference \\
\hline ISC-A & ISCfe1: tnpB gene & $764-843$ & This study \\
ISC-B & ISCfe1: thpA gene & $567-626$ & {$[10]$} \\
parA-A & parA gene & $321-406$ & {$[13]$, with modifications } \\
parA-B & parA gene & $84-161$ & This study \\
\hline
\end{tabular}

$n$ : number of samples tested; ${ }^{a}$ Nucleotide region of ISCfe1 and parA sequences with NCBI accession numbers AM260752.1 and CP043435.1: c1229121-1,228,459, respectively

developed to detect the $\operatorname{tnp} B$ gene of ISCfe1 (Table 4). The primers and probe (Additional file 2) were designed to target a $109 \mathrm{bp}$ sequence using Primer Express software v2.0 and specificity was assessed using BLAST search in the NCBI database. PCR reactions were performed in duplicate, in $20 \mu \mathrm{L}$ mixtures containing $1 \mathrm{x}$ SensiFAST probe Hi-ROX mastermix (Bioline Reagents Ltd), $400 \mathrm{nM}$ of each primer, $100 \mathrm{nM}$ of Taqman MGB probe and $25 \mathrm{ng}$ of total DNA. Amplifications were performed on a StepOnePlus system (Applied Biosystems), using the following thermal cycle conditions: 2 min incubation step at $50^{\circ} \mathrm{C}$, denaturation for $4 \mathrm{~min}$ at $95^{\circ} \mathrm{C}$, followed by 35 cycles of $10 \mathrm{~s}$ at $95^{\circ} \mathrm{C}$ and $30 \mathrm{~s}$ at $60^{\circ} \mathrm{C}$. The ISC-B assay targets the tnpA gene of ISCfe1, using previously published primers and probe [10]. PCR reaction mixtures and thermal cycle conditions were as previously described for ISC-A. Samples with a $\mathrm{Ct}<35$ were considered positive.

\section{Detection of parA gene: parA-A and parA-B assays}

The detection of parA gene also used two different Taqman MGB probe assays (parA-A and parA-B assays; Table 4). The parA-A assay is a real-time PCR assay previously described [13], with minor modifications (Additional file 2). The reverse primer was modified according to sequencing data of PCR products amplified with primers VENSF/VENSR [12] in the bovine preputial samples. All reactions were carried out in $20 \mu \mathrm{L}$ reaction volume, with $900 \mathrm{nM}$ of each primer, $250 \mathrm{nM}$ of Taqman MGB probe, 1x SensiFAST probe Hi-ROX mastermix and $25 \mathrm{ng}$ of DNA. Amplifications were performed on a Step One Plus System, using the thermal cycle conditions previously described [13]. The parA-B assay was designed to amplify a different sequence of the parA gene with 78 bp (Table 4). The primers and probe (Additional file 2) were designed using Primer Express software v2.0 and specificity was assessed using BLAST

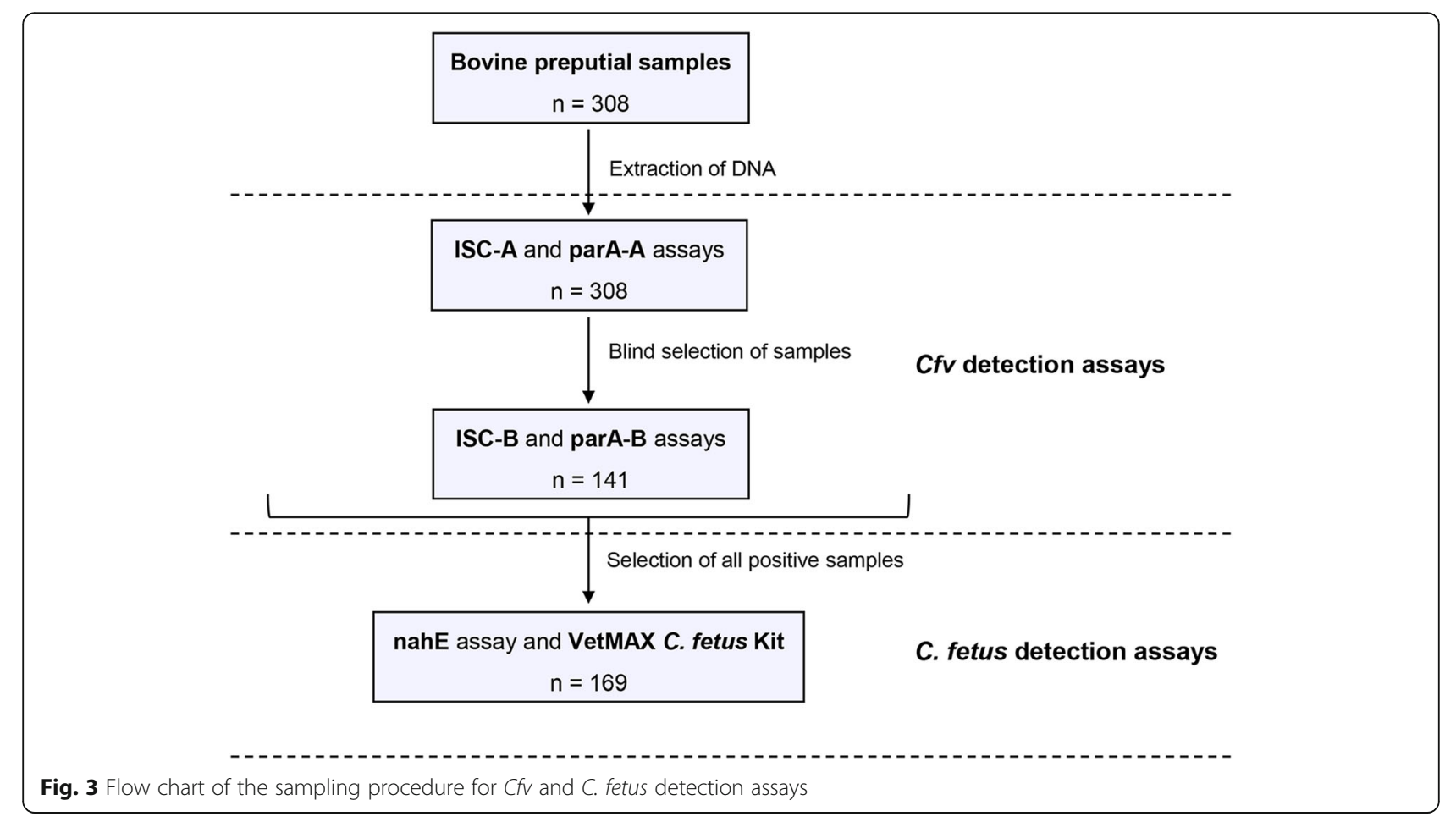


search in the NCBI database. PCR reaction mixtures and thermal cycle conditions were the same as described for ISC-A assay. Samples with a $\mathrm{Ct}<35$ in parA-A or parA$\mathrm{B}$ assays were considered positive.

\section{Detection of C. fetus species-specific targets: nahE and VetMAX C. fetus kit}

C. fetus detection was performed using a real-time PCR assay targeting the nahE gene and a commercial diagnostic kit (VetMAX C. fetus kit, Life Technologies) in all samples positive to ISCfe1 (ISC-A and/or ISC-B assays) and/or parA gene (parA-A and/or parA-B assay). The nahE gene was detected using previously described primers and probe [10], with the conditions described above for ISCfe1 amplification. Samples with a $\mathrm{Ct}<35$ were considered positive. Samples were also tested with VetMAX C. fetus kit following the instructions and validation criteria recommended by the manufacturer.

\section{Real-time PCR assays' performance: linearity, amplification efficiency and reproducibility}

The analytical performance of the real-time PCR assays was assessed in DNA extracted from preputial samples, spiked with genomic DNA from Cfv strain NCTC 10354. Standards were prepared using DNA from $C f v$ NCTC 10354, previously extracted with Qiagen DNeasy Blood and Tissue kit (Qiagen). The genomic DNA was quantified using a Nanodrop 2000C spectrophotometer and the number of $C f v$ genome copies was determined based on the strain's genome size $(1,874,244 \mathrm{bp})$, according to the formula: Number of copies $=($ DNA concentration $\left.(\mathrm{ng} / \mu \mathrm{L}) \times\left[6.022 \times 10^{23}\right]\right)$ / (length of template (bp) $\left.\mathrm{x}\left[1 \times 10^{9}\right] \times 650\right)$. Ten-fold dilutions were performed from $1.25 \times 10^{6}$ to $1.25 \times 10^{2}$ genome copies $/ \mu \mathrm{L}$. Then, DNA preputial samples of three bulls, previously tested as negative in the PCR assays under study, were spiked with ten-fold dilutions of Cfv NCTC 10354, representing $10^{1}$ to $10^{5}$ genome copies per $25 \mathrm{ng}$ of preputial sample DNA in $2 \mu \mathrm{L}$ of template (PCR reaction). These three sets of standards were aliquoted and stored at $-20^{\circ} \mathrm{C}$ until use. Three independent experiments were performed for each real-time PCR assay, one for each set of standards, all tested with two replicate wells per dilution. The performance of the real-time PCR assays was evaluated based on the linearity $\left(r^{2}\right)$, amplification efficiency (E) and reproducibility. The amplification efficiency was estimated based on the slope of the standard curve, using the formula: $E=10^{(-1 / \text { slope })}-1$. The reproducibility was evaluated using the inter-assay and intra-assay coefficients of variation (CV) for each dilution.

\section{Detection of genomic island genes in bovine preputial samples}

The presence of GI genes formerly considered $C f v$-specific, which include type 4 secretion system-coding genes (virB2virB11/virD4 genes), was assessed by conventional PCR. This $C f v$-associated genomic island may also include the parA gene and fic genes. Amplification of virB9 and virB11 was performed with previously described primers [11]. Primers for amplification of fic1 and fic2 (Additional file 2) were designed with Primer-BLAST [33] using the sequence of $C f v$ strain NCTC 10354 as a reference. These assays for fic1, fic2, virB9 and virB11 gene detection were performed in 49 samples, from which 30 parA negative and 19 parA positive in the parA-A assay. PCR reactions were carried out in $25 \mu \mathrm{L}$ mixtures containing $0.4 \mu \mathrm{M}$ of each primer, $400 \mu \mathrm{M}$ of each dNTP (4you4 dNTP Mix, Bioron), 1 x reaction buffer (Complete reaction buffer, Bioron), 2 units of DFS-Taq DNA polymerase (Bioron) and $150 \mathrm{ng}$ of DNA. Amplifications were performed in a Doppio thermal cycler (VWR) using the following conditions: $3 \mathrm{~min}$ at $94^{\circ} \mathrm{C}$, followed by 35 cycles of $94{ }^{\circ} \mathrm{C}$ for $30 \mathrm{~s}$, annealing temperature for $30 \mathrm{~s}$, and $72{ }^{\circ} \mathrm{C}$ for $1 \mathrm{~min}$, with a final extension step of $5 \mathrm{~min}$ at $72{ }^{\circ} \mathrm{C}$. The annealing temperatures selected for amplification of fic1/fic2, virB9 and virB11 were $57^{\circ} \mathrm{C}, 53^{\circ} \mathrm{C}$ and $56^{\circ} \mathrm{C}$, respectively. Amplification products were detected by electrophoresis on a $1.5 \%$ agarose gel stained with ethidium bromide and bands were visualized in a ChemiDoc XRS+ System (Biorad).

\section{Statistical analysis}

Statistical data analysis was performed using IBM SPSS Statistics for Windows, version 26.0 (IBM Corporation). To evaluate inter and intra-assay reproducibility of realtime PCR assays, the coefficient of variation of the $\mathrm{Ct}$ was calculated as follows: \% CV $=$ (standard deviation $\mathrm{Ct}$ $/$ mean Ct) $\times 100$. Agreement between results of different real-time PCR assays was evaluated using the Cohen's Kappa coefficient. Additionally, results were analysed using McNemar's test for testing the null hypothesis that methods were equally likely to identify samples as positive or negative. The presence of association between the detection of GI-associated genes and the detection of the parA gene was assessed using the phi $(\phi)$ coefficient. Values of $P<0.05$ were considered statistically significant.

\section{Supplementary Information}

The online version contains supplementary material available at https://doi. org/10.1186/s12917-020-02634-7.

Additional file 1. Agreement between assays directed towards the same molecular target. (a) Agreement between parA-A and parA-B assays, (b) Agreement between ISC-A and ISC-B assays.

Additional file 2. Primers and probes used in real time PCR assays. 


\section{Abbreviations}

BGC: Bovine Genital Campylobacteriosis; Cff: Campylobacter fetus subsp. fetus; Cfv: Campylobacter fetus subsp. venerealis; Ct: Threshold cycle; CV: Coefficient of variation; Gl: Genomic island

\section{Acknowledgements}

Not applicable.

\section{Authors' contributions}

MFS contributed to investigation, data analysis and wrote the manuscript (original draft); AD contributed to investigation; GP analysed data and revised the manuscript; LM revised the manuscript; LLdC and ES contributed to conceptualization, methodology, funding acquisition and manuscript revision/editing. All authors read and approved the final manuscript.

\section{Funding}

This study was supported by Fundação para a Ciência e a Tecnologia (FCT), under the project PTDC/CVT-CVT/30145/2017, co-funded by the European Regional Development Fund. In addition, the study was funded by Centro de Investigação Interdisciplinar em Sanidade Animal - CIISA (Project UIDP/ CVT/00276/2020, funded by FCT). Marta Silva and Gonçalo Pereira are PhD students supported by grants from FCT, SFRH/BD/125657/2016 and SFRH/ BD/130923/2017, respectively. Elisabete Silva is funded by FCT (DL 57/2016/ CP1438/CT0001). The funders had no role in study design, data collection and analysis, decision to publish, or preparation of the manuscript.

\section{Availability of data and materials}

The Whole Genome Shotgun project of Campylobacter portucalensis is deposited at DDBJ/ENA/GenBank under the accession number WSJ00000000.1, which includes the insertion sequence (Contig 29, WSJ01000029.1) and the genomic island (Contig 27, WWSJ01000027.1). Other datasets used and/or analysed during the current study are available from the corresponding author upon request.

\section{Ethics approval and consent to participate}

The bovine preputial samples were collected by certified veterinarians, using the OIE recommended sampling method, as part of the breeding soundness examination of bulls, and as a clinical service requested by owners to the Faculty of Veterinary Medicine of the University of Lisbon. Since all samples were collected for diagnostic purposes, according to EU and national legislation (Directive 2010/63/EU and Decree-law no. 113/2013, respectively) no ethical approval from an Institutional Animal Care and Use Committee or other relevant ethics board was required. According to the regulation of the Veterinary Teaching Hospital of the Faculty of Veterinary Medicine of the University of Lisbon, which is publicly available, all clinical and diagnostic procedures and records may be used for teaching and research purposes, always respecting its confidentiality. Despite this, animal owners were informed and verbal consent was obtained to use data from their animals in the study.

\section{Consent for publication}

Not applicable.

\section{Competing interests}

The authors declare that they have no competing interests.

Received: 29 June 2020 Accepted: 21 October 2020 Published online: 29 October 2020

\section{References}

1. Michi AN, Favetto PH, Kastelic J, Cobo ER. A review of sexually transmitted bovine trichomoniasis and campylobacteriosis affecting cattle reproductive health. Theriogenology. 2016;85(5):781-91. https://doi.org/10.1016/j. theriogenology.2015.10.037..

2. OIE (World Organization for Animal Health). Bovine genital campylobacteriosis. In: Manual of diagnostic tests and vaccines for terrestrial animals, 8th edition. Paris: OIE; 2018. p. 1031-44.

3. Cobo ER, Corbeil LB, BonDurant RH. Immunity to infections in the lower genital tract of bulls. J Reprod Immunol. 2011;89(1):55-61. https://doi.org/10. 1016/j.jri.2011.02.002.
4. van Bergen MA, Linnane S, van Putten JPM, Wagenaar JA. Global detection and identification of Campylobacter fetus subsp. venerealis. Rev Sci Tech. 2005;24(3):1017-26.

5. van Bergen MAP, Dingle KE, Maiden MCJ, Newell DG, van der Graaf-van Bloois L, van Putten JPM, et al. Clonal nature of Campylobacter fetus as defined by multilocus sequence typing. J Clin Microbiol. 2005;43(12):588898. https://doi.org/10.1128/JCM.43.12.5888-5898.2005.

6. van der Graaf-van Bloois L, Miller WG, Yee E, Rijnsburger M, Wagenaar JA, Duim B. Inconsistency of phenotypic and genomic characteristics of Campylobacter fetus subspecies requires reevaluation of current diagnostics. J Clin Microbiol. 2014;52(12):4183-8. https://doi.org/10.1128/JCM.01837-14.

7. Mai HM, Irons PC, Kabir J, Thompson PN. Prevalence of bovine genital campylobacteriosis and trichomonosis of bulls in northern Nigeria. Acta Vet Scand. 2013;55(1):56. https://doi.org/10.1186/1751-0147-55-56.

8. Chang W, Ogg JE. Transduction and mutation to glycine tolerance in Vibrio fetus. Am J Vet Res. 1971;32(4):649-53.

9. McGoldrick A, Chanter J, Gale S, Parr J, Toszeghy M, Line K. Real time PCR to detect and differentiate Campylobacter fetus subspecies fetus and Campylobacter fetus subspecies venerealis. J Microbiol Methods. 2013;94(3): 199-204. https://doi.org/10.1016/j.mimet.2013.06.014.

10. van der Graaf-van Bloois L, van Bergen MA, van der Wal FJ, de Boer AG, Duim B, Schmidt T, et al. Evaluation of molecular assays for identification Campylobacter fetus species and subspecies and development of a C. fetus specific real-time PCR assay. J Microbiol Methods. 2013;95(1):93-7. https:// doi.org/10.1016/j.mimet.2013.06.005.

11. Moolhuijzen PM, Lew-Tabor AE, Wlodek BM, Agüero FG, Comerci DJ, Ugalde RA, et al. Genomic analysis of Campylobacter fetus subspecies: identification of candidate virulence determinants and diagnostic assay targets. BMC Microbiol. 2009;9:86. https://doi.org/10.1186/1471-2180-9-86.

12. Hum S, Quinn K, Brunner J, On SL. Evaluation of a PCR assay for identification and differentiation of Campylobacter fetus subspecies. Aust Vet J. 1997;75:827-31.

13. McMillen L, Fordyce G, Doogan VJ, Lew AE. Comparison of culture and a novel 5'Taq nuclease assay for direct detection of Campylobacter fetus subsp. venerealis in clinical specimens from cattle. J Clin Microbiol. 2006;44: 938-45. https://doi.org/10.1128/JCM.44.3.938-945.2006.

14. Abril C, Vilei EM, Brodard I, Burnens A, Frey J, Miserez R. Discovery of insertion element ISCfe1: a new tool for Campylobacter fetus subspecies differentiation. Clin Microbiol Infect. 2007;13(10):993-1000. https://doi.org/ 10.1111/j.1469-0691.2007.01787.x.

15. Iraola G, Hernández M, Calleros L, Paolicchi F, Silveyra S, Velilla A, et al. Application of a multiplex PCR assay for Campylobacter fetus detection and subspecies differentiation in uncultured samples of aborted bovine fetuses. J Vet Sci. 2012;13:371-6. https://doi.org/10.4142/jvs.2012.13.4.371.

16. Chaban B, Chu S, Hendrick S, Waldner C, Hill JE. Evaluation of a Campylobacter fetus subspecies venerealis real-time quantitative polymerase chain reaction for direct analysis of bovine preputial samples. Can J Vet Res. 2012;76:166-73.

17. Guerra AG, Chaban B, Hill JE, Waldner CL, Hendrick SH. Clinical sensitivity and specificity of a real-time PCR assay for Campylobacter fetus subsp. venerealis in preputial samples from bulls. Am J Vet Res. 2014;75:851-60. https://doi.org/10.2460/ajvr.75.9.851.

18. Waldner CL, Parker S, Gesy KM, Waugh T, Lanigan E, Campbell JR. Application of direct polymerase chain reaction assays for Campylobacter fetus subsp. venerealis and Tritrichomonas foetus to screen preputial samples from breeding bulls in cow-calf herds in western Canada. Can J Vet Res. 2017;81:91-9.

19. Broeders S, Huber I, Grohmann L, Berben G, Taverniers I, Mazzara M, et al. Guidelines for validation of qualitative real-time PCR methods. Trends Food Sci Technol. 2014;37:115-26.

20. Silva MF, Pereira G, Carneiro C, Hemphill A, Mateus L, Lopes da Costa L, et al. Campylobacter portucalensis sp. nov., a new species of Campylobacter isolated from the preputial mucosa of bulls. PLoS One. 2020;15:e0227500. https://doi.org/10.1371/journal.pone.0227500.

21. Willoughby K, Nettleton PF, Quirie M, Maley MA, Foster G, Toszeghy M, et al. A multiplex polymerase chain reaction to detect and differentiate Campylobacter fetus subspecies fetus and Campylobacter fetus -species venerealis: use on UK isolates of C. fetus and other Campylobacter spp. J Appl Microbiol. 2005;99:75866. https://doi.org/10.1111/j.1365-2672.2005.02680.x.

22. Spence RP, Bruce IR, McFadden AM, Hill Fl, Tisdall D, Humphrey S, et al. Cross-reaction of a Campylobacter fetus subspecies venerealis real-time PCR. Vet Rec. 2011;168:131. https://doi.org/10.1136/vr.c5264. 
23. Abril C, Brodard I, Perreten V. Two novel antibiotic resistance genes, tet(44) and ant (6)-Ib, are located within a transferable pathogenicity island in Campylobacter fetus subsp. fetus. Antimicrob Agents Chemother. 2010;54: 3052-5. https://doi.org/10.1128/AAC.00304-10.

24. Sanhueza JM, Heuer C, Jackson R, Hughes P, Anderson P, Kelly K, et al. Pregnancy rates of beef cattle are not affected by Campylobacter fetus subsp. venerealis real-time PCR-positive breeding sires in New Zealand. N Z Vet J. 2014;62:237-43. https://doi.org/10.1080/00480169.2014.898202.

25. García-Guerra A, Waldner CL, Pellegrino A, Macdonald N, Chaban B, Hill JE, et al. Effect of sample pooling and transport conditions on the clinical sensitivity of a real-time polymerase chain reaction assay for Campylobacter fetus subsp. venerealis in preputial samples from bulls. Can J Vet Res. 2016; 80(1):32-9.

26. Gorkiewicz G, Kienesberger S, Schober C, Scheicher SR, Gülly C, Zechner R, et al. A genomic island defines subspecies-specific virulence features of the host-adapted pathogen Campylobacter fetus subsp. venerealis. J Bacteriol. 2010;192(2):502-17. https://doi.org/10.1128/JB.00803-09.

27. van der Graaf-van Bloois L, Miller WG, Yee E, Gorkiewicz G, Forbes KJ, Zomer AL, et al. Campylobacter fetus subspecies contain conserved type IV secretion systems on multiple genomic islands and plasmids. PLoS One. 2016;11(4):e0152832. https://doi.org/10.1371/journal.pone.0152832.

28. Oliveira JMB, Silva GM, Filho AFB, Borges JM, Oliveira PRF, Brandespim DF, et al. Prevalence and risk factors associated with bovine genital campylobacteriosis and bovine trichomonosis in the state of Pernambuco, Brazil. Trop Anim Health Prod. 2015;47(3):549-55. https://doi.org/10.1007/ s11250-015-0761-3.

29. Filho RBO, Malta KC, Lúcio EC, Nascimento GG, Dutra LC, Mota RA, et al. Prevalence of Campylobacter fetus subsp. venerealis in dairy cows from Brejo Paraibano, Brazil. Acta Sci Vet. 2018;46:1526.

30. Lúcio EC, Barros MR, Mota RA, Maia RCC, Pinheiro JW Jr. Identification of Campylobacter fetus subsp. venerealis virulence genes in cervical mucus from cows. Braz J Microbiol. 2019;50(4):1133-7. https://doi.org/10.1007/ s42770-019-00127-w.

31. van der Graaf-van Bloois L. Molecular characterization and differentiation of Campylobacter fetus subspecies. Doctoral Thesis: Utrecht University; 2016. Available from: http://dspace.library.uu.n//handle/1874/342332. Accessed 27 Mar 2020.

32. Silveira CS, Fraga M, Giannitti F, Macías-Rioseco M, Riet-Correa F. Diagnosis of bovine genital campylobacteriosis in South America. Front Vet Sci. 2018; 5:321. https://doi.org/10.3389/fvets.2018.00321.

33. Ye J, Coulouris G, Zaretskaya I, Cutcutache I, Rozen S, Madden TL. PrimerBLAST: a tool to design target-specific primers for polymerase chain reaction. BMC Bioinformatics. 2012;13:134. https://doi.org/10.1186/14712105-13-134.

\section{Publisher's Note}

Springer Nature remains neutral with regard to jurisdictional claims in published maps and institutional affiliations.

Ready to submit your research? Choose BMC and benefit from:

- fast, convenient online submission

- thorough peer review by experienced researchers in your field

- rapid publication on acceptance

- support for research data, including large and complex data types

- gold Open Access which fosters wider collaboration and increased citations

- maximum visibility for your research: over $100 \mathrm{M}$ website views per year

At $\mathrm{BMC}$, research is always in progress.

Learn more biomedcentral.com/submissions 